\title{
Briefing: Bamboo for construction in Pakistan - a scoping review
}

\author{
Elizabeth Wagemann BArch, MArch, MPhil, PhD \\ Research Associate, Department of Architecture, University of Cambridge, \\ Cambridge, UK (corresponding author: ewagemann@cantab.net) \\ (Orcid:0000-0001-9321-3096)
}

Michael H. Ramage MArch, PhD

Senior University Lecturer, Department of Architecture, University of Cambridge, Cambridge, UK (Orcid:0000-0003-2967-7683)

This scoping review explores the bamboo construction situation in Pakistan, including the species available, where they grow, built examples, perceptions, barriers to their use and the potential of the material, aiming to enable state-of-the-art use of bamboo in the country.

\section{Introduction}

Bamboo is a renewable material available worldwide in tropical, subtropical and temperate zones for use in construction, furniture, handicrafts and food. It has shown advantages as a construction material because it is a rapidly renewable sustainable resource and it has mechanical properties similar to those of timber (Sharma et al., 2015). Despite these advantages, the quality and potential of bamboo as a construction material depend on good growing practices, cutting techniques, treatment and preservation, correct jointing, overall structural design and maintenance.

Between 2005 and 2016 more than 5100000 people were left homeless due to earthquakes and floods in Pakistan (Cred EM-DAT, 2017). In response to these events, different emergency, transitional and permanent shelters were built and many of them used bamboo with various degrees of success, acceptability and durability. Bamboo offers an affordable and sustainable solution for shelter; however, there are limited resources to guide communities on how best to use it. The main research question for this scoping review was 'what types of bamboo species are suitable for construction purposes in Pakistan?' The main objective was to map the range of species for the four primary systems: poles and columns (large diameter); rafters and studs (medium diameter); roof and wall battens (medium and small diameters); and wall and floor cladding (small diameter). In addition, this research looked for examples in construction, perceptions and barriers to the use of bamboo in Pakistan.

\section{Bamboo species in Pakistan suitable for construction purposes}

There are around 1200 species of bamboo globally and among these, three are native to Pakistan: Arundinaria falcata, Bambusa bamboo and Dendrocalamus strictus (Lobovikov et al., 2007). Of these, A. falcata has been recorded in the North West Himalayas at 1200-2000 m and B. bamboo has been cultivated in Punjab and Sindh, and has occasionally been found in the Ravi River to the east (Ahmad, 1997; Suleman, 2005). D. strictus has been recorded in the Margalla Hills, Chattar, the Eastern Salt Range, Shahpur and Mirpur, Ambela, Maskipur and Bagra in Burner up to an altitude of $800 \mathrm{~m}$ (Siddiqui, 1994). These sites lie at the limit of Chir pine-growing areas, indicating that bamboo used to grow as a scattered undergrowth in forests, between 350 and $800 \mathrm{~m}$ of altitude, and it was more widespread than it is now (Siddiqui, 1994). Some reasons for its decrease might be the cutting and removal of native groves, and the effects of fire, grazing and drought (Siddiqui, 1994). A number of species were introduced to the country; some authors indicate that 13 new species were introduced from China, Bangladesh, Sri Lanka and Thailand (Lobovikov et al., 2007), while others say that 25 species were brought (Siddiqui, 1994; Suleman, 2005). Although some species grew successfully, others did not adapt due to poor post-harvesting and processing, leading to a fall in prices and plantations being uprooted (Rao and Ouedraogo, 1997).

A map of bamboo growth areas in Pakistan (Figure 1) and a table showing the bamboo species (Table 1) were created to show the information found in this scoping review. The districts of the Punjab province where bamboo is established in agricultural lands are Sargodha, Jhang, Kasur, Lahore, Khushab, Ganda Singh, Bhalwal, Mandi Bhahaudin and Dera Ghazi Khan (Karim Alm-Ns, 2016; Lobovikov et al., 2007; Suleman, 2005), and the major species cultivated on private farmland are D. strictus, Bambusa tulda and Dendrocalamus hamiltonii (Lobovikov et al., 2007; Suleman, 2005). These three species are used extensively for construction (Bauer, 2010; Ward et al., 2010).

\section{Local market for bamboo in Pakistan}

Almost all of the demand for bamboo in Pakistan was met up to 1971 from the native forests of East Pakistan, but after the creation of Bangladesh, the prices of goods manufactured with bamboo increased (Siddiqui, 1994). However, in the 


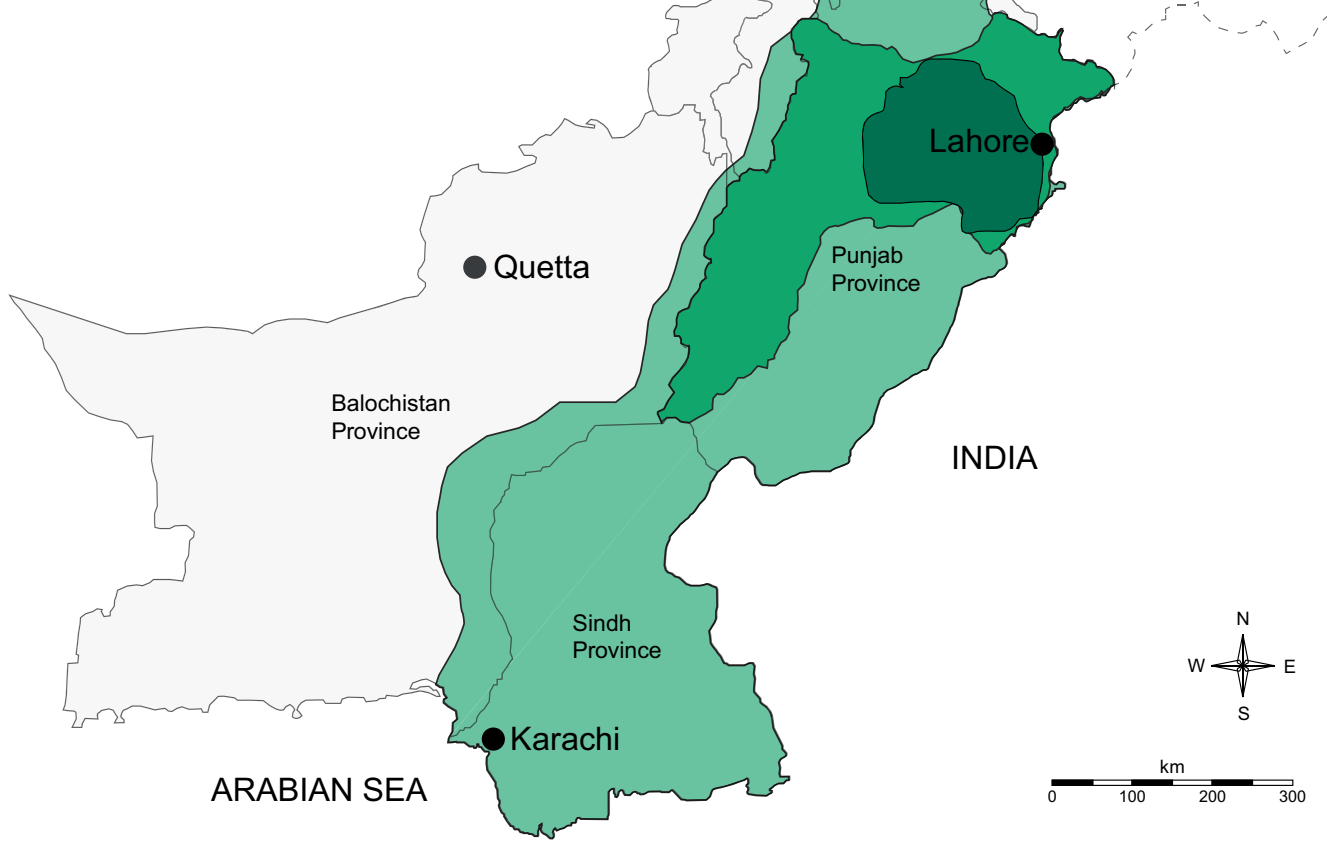

Figure 1. Map of bamboo growing areas in Pakistan. Sources: Based on information from (1) Suleman (2005), (2) Karim Alm-Ns (2016) and (3) Bystriakova et al. (2003)

late 1970 s and early 1980 s bamboo started to be cultivated in the country and the government allowed importation, which contributed to lowering prices (Siddiqui, 1994). In the last few decades, almost all bamboo resources have been grown on private farms in the Punjab region where most farmers use rhizomes for planting bamboos, although shoot cuttings are also used for cultivation (Suleman, 2005). While generally small, plantation areas increase or decrease with market demand and timber prices (Suleman, 2005). Bamboo grown for 3-4 years is used as structural support for dikes and for construction purposes, and bamboo grown on a 2-year cycle is commonly used for the paper pulp industry (Ward et al., 2010).

It was estimated in 2005 that the average stock of bamboo grown on farmlands was $8 \mathrm{t} / \mathrm{ha}$ and that the total growing stock of bamboo for commercial purposes was $136000 \mathrm{t}$ for material with a culm diameter of $>5 \mathrm{~cm}$ (Suleman, 2005).
Most bamboo farmers sell to traders who clear-cut the bamboo, coordinate transportation and sell the material to retailers or paper pulp factories (Ward et al., 2010). There is little seasonal variation in prices or supply because bamboo is mostly harvested year round, and prices increase by $\sim 5 \%$ every 2 years (Bauer, 2010; Ward et al., 2010), almost in line with inflation, on average by 4\% in 2016 (Trading Economics, 2017).

Inter-agency assessments of the impact of the monsoon floods of 2010 on market systems in Pakistan indicate that there were neither significant crop losses nor an impact on the bamboo market immediately after the floods (Bauer, 2010; Ward et al., 2010). However, demand for bamboo for reconstruction started to increase 6 months after the floods, and a year later prices hit their peak of Pakistani rupee (PKR) 15-16 per foot, approximately twice the normal retail price of PKR 7-8 (Zyck et al., 2015). The reasons for the increase were scarcity due to the use of bamboo for shelters and water and sanitation 
Table 1. Bamboo species in Pakistan. Based on information from Chao and Renvoize (1989), Siddiqui (1994), Ahmad (1997), Rao and Ouedraogo (1997), Bystriakova et al. (2003), Suleman (2005), Lobovikov et al. (2007) and Zehui (2007)

\begin{tabular}{|c|c|c|c|c|}
\hline Species & Description & $\begin{array}{l}\text { Height: } \\
\text { m }\end{array}$ & $\begin{array}{l}\text { Diameter: } \\
\text { cm }\end{array}$ & Possible use \\
\hline \multicolumn{5}{|l|}{ Native } \\
\hline Arundinaria falcata & $\begin{array}{l}\text { Grows in the undergrowth in forests of oak, usually } \\
\text { on northern slopes or in ravines. It is used for } \\
\text { making baskets, mats and pipes }\end{array}$ & ND & ND & $\begin{array}{l}\text { Wall and floor } \\
\text { cladding }\end{array}$ \\
\hline Bambusa bamboo & $\begin{array}{l}\text { (Cultivated) This species is extensively used for } \\
\text { construction }\end{array}$ & 30 & 18 & Poles/columns \\
\hline Dendrocalamus Strictus & $\begin{array}{l}\text { (Cultivated) Used for construction, pulp and paper } \\
\text { and a variety of purposes. This forms part of a } \\
\text { gene pool extending across Hindustan and usually } \\
\text { seen in hilly areas ascending to } 800 \mathrm{~m} \text { and up to } \\
1200 \mathrm{~m}\end{array}$ & $6-20$ & $3-15$ & Rafters and studs \\
\hline \multicolumn{5}{|l|}{ Introduced, most successful } \\
\hline Bambusa multiplex & $\begin{array}{l}\text { (Cultivated) This is a hedge bamboo, introduced } \\
\text { from China. It is cultivated for general use and } \\
\text { paper pulp }\end{array}$ & $7-10$ & $2 \cdot 5-4$ & $\begin{array}{l}\text { Wall and floor } \\
\text { cladding }\end{array}$ \\
\hline $\begin{array}{l}\text { Bambusa tulda (Bengal or } \\
\text { java bamboo) }\end{array}$ & $\begin{array}{l}\text { Used for construction, scaffolding, furniture, fodder } \\
\text { and edible shoots. Also used for pulp and paper, } \\
\text { toys, mats, screens, baskets and fishing rods. } \\
\text { Native of Assam, Thailand, Bangladesh and } \\
\text { Myanmar }\end{array}$ & $15-23$ & $7-10$ & $\begin{array}{l}\text { Rafters and studs, } \\
\text { roof and wall } \\
\text { battens }\end{array}$ \\
\hline $\begin{array}{l}\text { Bambusa vulgaris } \\
\text { (golden bamboo) }\end{array}$ & $\begin{array}{l}\text { (Cultivated) Extensively used for furniture, construction } \\
\text { and edible shoots. From tropical Asia it has been } \\
\text { introduced in tropical and subtropical regions in } \\
\text { the world }\end{array}$ & 20 & 10 & Rafters and studs \\
\hline Dendrocalamus giganteus & $\begin{array}{l}\text { (Cultivated) Used for construction, fodder and } \\
\text { edible shoots. Found in tropical and subtropical } \\
\text { regions }\end{array}$ & 30 & $25-30$ & Poles/columns \\
\hline $\begin{array}{l}\text { Dendrocalamus hamiltonii } \\
\text { (kala baans) }\end{array}$ & $\begin{array}{l}\text { Used for fodder, weaving and edible shoots, also } \\
\text { for scaffolding, construction, basket making and } \\
\text { mats. Naturally found in India, Bhutan and } \\
\text { Bangladesh }\end{array}$ & 30 & $5-13$ & $\begin{array}{l}\text { Rafters and studs, } \\
\text { roof and wall } \\
\text { battens }\end{array}$ \\
\hline Dendrocalamus longispathus & $\begin{array}{l}\text { (Cultivated) Used for making baskets and ornamental } \\
\text { items. Found in India, Myanmar and Bangladesh }\end{array}$ & $12-18$ & $7-13$ & Rafters and studs \\
\hline $\begin{array}{l}\text { Phyllostachys aurea (fishpole } \\
\text { or golden bamboo) }\end{array}$ & $\begin{array}{l}\text { (Cultivated) Used for furniture, edible shoots, } \\
\text { handicrafts and as an ornamental bamboo. Native } \\
\text { to China but cultivated in Japan and introduced to } \\
\text { other countries as ornamental species. It withstands } \\
\text { temperatures down to }-17 \cdot 7^{\circ} \mathrm{C} \text {. }\end{array}$ & $9-12$ & 9 & $\begin{array}{l}\text { Wall and floor } \\
\text { cladding }\end{array}$ \\
\hline \multicolumn{5}{|l|}{ Introduced, others } \\
\hline $\begin{array}{l}\text { Bambusa arundinacea } \\
\text { (thorny bamboo) }\end{array}$ & $\begin{array}{l}\text { Used for construction, pulping, tools and edible } \\
\text { shoots. Split culms used for mats and basket work. } \\
\text { Mainly in India, Sri Lanka, Thailand, Indonesia and } \\
\text { Myanmar (Burma). It grows rapidly }(50 \cdot 8 \mathrm{~cm} / \mathrm{d})\end{array}$ & $17-30$ & $9-18$ & Rafters and studs \\
\hline Bambusa nutans & $\begin{array}{l}\text { Medium size bamboo used as an ornament and in } \\
\text { the paper industry. Native in India and cultivated } \\
\text { in Bangladesh and Thailand }\end{array}$ & $6-15$ & $5-10$ & Rafters and studs \\
\hline Bambusa polymorpha & $\begin{array}{l}\text { Used for construction. Popular for roofing and } \\
\text { flooring. Found in India, Indonesia, Bangladesh, } \\
\text { Thailand, Myanmar and China }\end{array}$ & $15-25$ & $7-17$ & $\begin{array}{l}\text { Rafters and studs, } \\
\text { Wall and floor } \\
\text { cladding }\end{array}$ \\
\hline Melocanna bambusoides & $\begin{array}{l}\text { Used for building houses, woven ware, pulp and } \\
\text { paper, tabashir, toys, mats, screens and umbrella } \\
\text { sticks. Found in Eastern Bengal, Myanmar and } \\
\text { Chittagong, Bangladesh }\end{array}$ & $12-21$ & $2-8$ & $\begin{array}{l}\text { Wall and floor } \\
\text { cladding }\end{array}$ \\
\hline $\begin{array}{l}\text { Phyllostachys aureosulcata } \\
\text { (yellow groove bamboo) }\end{array}$ & $\begin{array}{l}\text { Used for gardening and ornaments. Found in } \\
\text { China, Europe and America }\end{array}$ & $5-10$ & $1-3$ & $\begin{array}{l}\text { Wall and floor } \\
\text { cladding }\end{array}$ \\
\hline $\begin{array}{l}\text { Phyllostachys pubescens } \\
\text { (moso bamboo) }\end{array}$ & $\begin{array}{l}\text { Giant hardy bamboo used for construction } \\
\text { and shoots. Native to China and also cultivated } \\
\text { in Japan }\end{array}$ & $12-22$ & $10-18$ & Poles/columns \\
\hline
\end{tabular}


facilities, and the willingness of aid agencies to pay abovemarket prices (Zyck et al., 2015). Also, transport costs were raised due to the longer routes taken to avoid flood-damaged roads and bridges, and due to middlemen involved in the trade (Zyck et al., 2015). Aid agencies drove up the quality of bamboo, pushing traders to stock more durable, extra thick, hence more expensive, bamboo (Zyck, 2014), inflating its price. Some local traders learned from experience and the bamboo sector grew in Sindh: larger dealers began to order more bamboo to be prepared in case of future flooding and began using raised shelving in their warehouses to prevent floods from damaging the stock (Zyck et al., 2015). Due to the demand, when needed, importers bring additional bamboo from China, Bangladesh and other countries to supplement local production (Zyck et al., 2015).

\section{Local knowledge in bamboo construction in Pakistan}

Bamboo is mainly used as a roofing material and scaffolding; however, it is also used to build latrines, ladders, carts and temporary shelters (Zyck et al., 2015). Some examples were found of bamboo used as an important structural element in buildings.

\subsection{Case 1: Emergency and transitional shelters after a disaster}

After the 2010 floods in Pakistan, millions of people needed temporary shelters across five provinces of the country (IFRC et al., 2014). Among different strategies to provide housing, traditional and local building designs and materials were encouraged, adapted and improved to achieve flood resistance and minimal environmental impact (IFRC et al., 2014). Some shelter programmes used bamboo in a 'versatile roofing kit', including bamboo poles, steel beams and plastic sheets, which were used for an emergency house first, the roof of the transitional house later and finally material for the permanent house (Figure 2).

\subsection{Case 2: Heritage Foundation of Pakistan}

The Heritage Foundation of Pakistan (HFP) is a not-for-profit organisation engaged in the research, dissemination and conservation of Pakistan's cultural heritage (HFP, 2011a). The organisation worked on several projects for the rehabilitation of communities affected by the earthquake in the Kashmir region in 2005 and the monsoon floods in 2010. The foundation designed and built community buildings that are elevated from the ground, which effectively resisted the 2011 floods (HFP, 2011a). The structures of these buildings were made of bamboo, covered with mud plaster on the first floor, built on stilts and had a circular plan (Figure 3). Also, the organisation developed a roof system called karavan roofs designed for refuge during floods (HFP, 2011b). The United Nations International Organisation for Migration (IOM) adopted the models from the HFP and applied them in the One Room Shelter programme (Figure 4) after the 2010 and 2011 floods, building 22800 shelters in Sindh province (IOM, 2014).

\subsection{Case 3: Tipu Sultan Merkez school in Jar Maulvii, Punjab}

This is a privately initiated school and development in the small village of Jar Maulwi, near Lahore, overseen by the organisation Tipu Sultan Merkez (TSM). The German firm Ziegert Roswag Seiler Architekten Ingenieure (ZRSAI) was in charge of the design and construction, in collaboration with the local architect Ghayyoor Syed Obaid. The project (Figures 5 and 6)
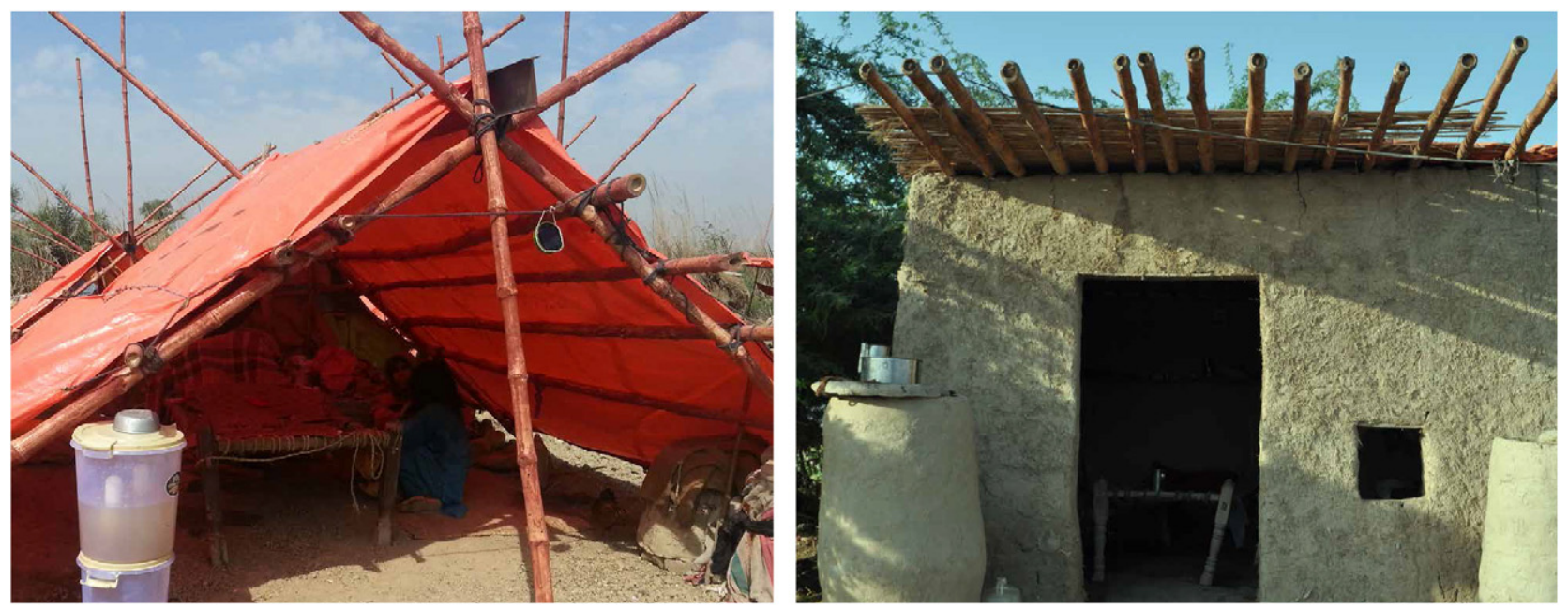

Figure 2. Bamboo in emergency roofing kit (left) that is later used in a transitional shelter (right). Courtesy of Magnus Wolfe Murray 


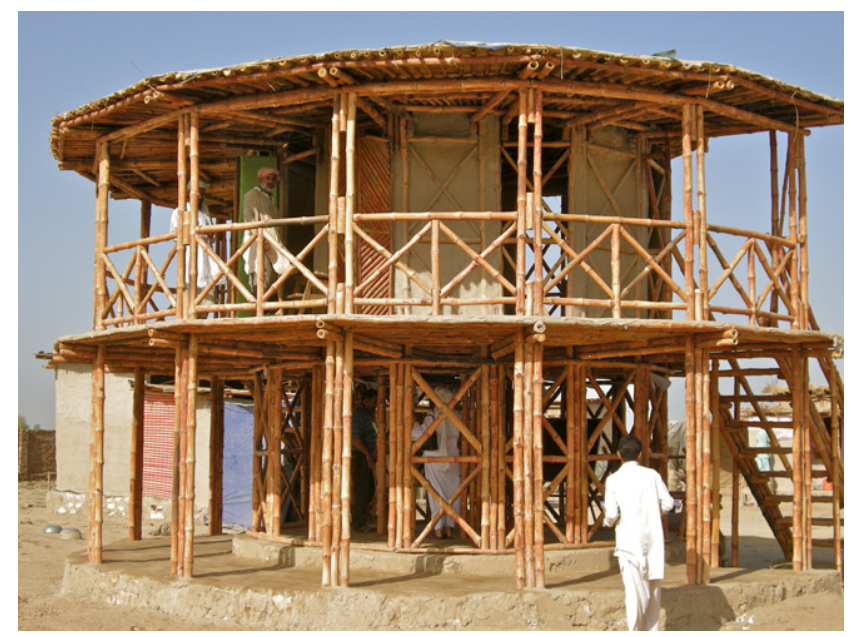

Figure 3. A green women's centre built on stilts. Courtesy of HFP

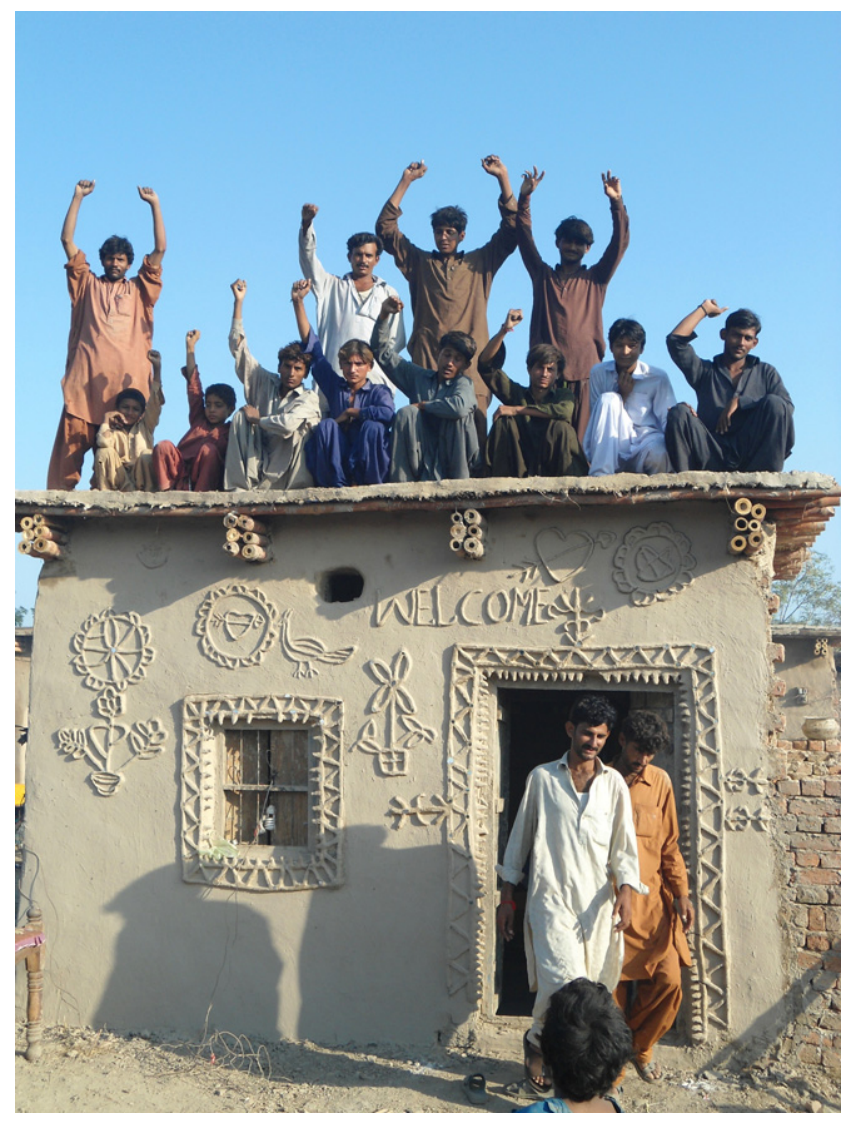

Figure 4. House built under the programme 'One Room Shelter' by IOM based on HFP's design. Courtesy of HFP

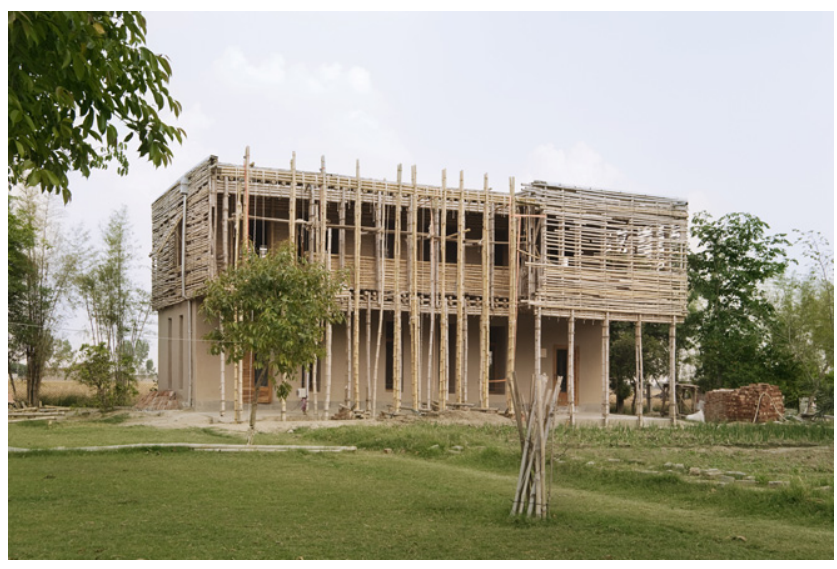

Figure 5. Building finished. TSM school in Jar Maulwi, Punjab. Courtesy of ZRSAI

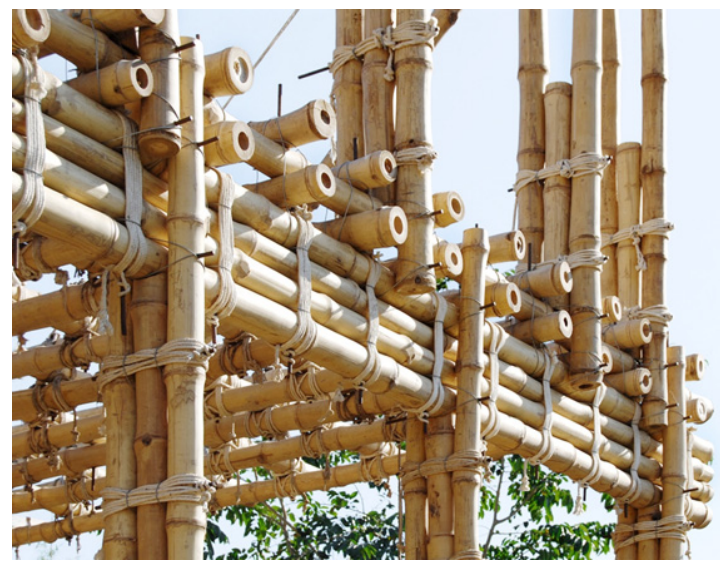

Figure 6. Construction process. TSM school in Jar Maulwi, Punjab. Courtesy of ZRSAI

follows earthquake design strategies using a brick foundation, $60 \mathrm{~cm}$ thick cob (earth and straw) walls on the ground floor, light bamboo frame structures filled with earth on the first floor, and a roof comprised of triple-layer bamboo beams joined with simple knots and steel rods covered with a layer of earth (ZRSAI, 2012). The bamboo frame structure is filled with straw-earth from inside and uses bamboo strips to create the exterior façade, which also overhangs the earth walls on the ground floor to protect them from rain (ZRSAI, 2012).

\section{Perceptions, barriers and potential of bamboo in Pakistan}

Some documents referenced in this paper explain a consumer preference for masonry houses in Pakistan, instead of timber or bamboo houses, due to an aspiration for 'durable concrete 
and brick homes', even though these are less comfortable and more expensive (Bauer, 2010; ZRSAI, 2012). To complement this information, some interviews were conducted using convenience sampling as a method (with six experts in sustainability and disaster relief from different areas of Pakistan). No statistical conclusions can be drawn from the interviews, which only aimed to get a general idea of how bamboo is seen as a material for construction in Pakistan.

Perceptions: Bamboo is mainly recognised as a material used in rural areas and seen as 'part of the past' by those who aspire to have a 'modern' house. Some do not perceive the material as local, although others recognise bamboo as used extensively for the construction of ladders, scaffolding, animal sheds, general shading, furniture, ornamental landscape, roofing, and emergency and temporary shelters. Barriers: The small amount of knowledge about the possibilities of bamboo in construction limits its use. Also, the lack of appropriate techniques in the cutting, treatment and building processes results in bad-quality material, which discourages people from using it. The techniques used for building with natural materials take longer and people are not trained in them.

Potential: Bamboo is seen as an alternative to timber in some areas and it could contribute to tackling deforestation. There is growing interest in low-cost sustainable materials, and bamboo is seen as offering an opportunity in this area. Also, due to the recurrent floods in the country, there is a need for quick renewable materials that can be available for reconstruction.

\section{Conclusion}

This scoping review shows that information available about the types of bamboo growing in Pakistan and the areas where bamboo grows is very limited. However, the review allowed the identification of the species of bamboo that are cultivated in the country and their possible uses in construction. The review also shows that more research needs to be conducted and disseminated.

Regarding examples of buildings that use bamboo, during a consultation exercise and in the interviews, it was mentioned that bamboo is extensively used for transitional shelters and as a roofing material for vernacular houses. Despite this, few examples were found in the literature, except for those referring to post-disaster shelters and one case of a school built with bamboo.

Finally, in terms of perception, despite some barriers to the use of bamboo in construction, this material is seen as an alternative for sustainable, resilient and low-cost construction that could be used in the country, not only for temporary dwellings but also for permanent ones, if well cut, treated, designed and built.

\section{Acknowledgements}

The authors acknowledge the University of Cambridge and the experts who participated in a consultation exercise in January 2017 who helped identify the best available information on bamboo in Pakistan. This work was supported by the EPSRC Global Challenge Research Fund, Institutional Grant 2016, EP/P510932/1.

\section{REFERENCES}

Ahmad Z (1997) A note on bamboo in Pakistan. In Proceedings of a Workshop Held at the Institute of Forestry, Pokhara, Nepal (Karki M, Rao AN, Ramanatha VR and Williams JT (eds)). INBAR, New Delhi, India, p. 215.

Bauer R (2010) Bamboo/Timber Markets in Pakistan after the 2010 Monsoon Floods. Key Issues in Supply and Demand. Emergency Market Mapping and Analysis (Emma), Sindh, Pakistan.

Bystriakova N, Kapos V, Stapleton C and Lysenko I (2003) Bamboo Biodiversity. Information for Planning Conservation and Management in the Asia-Pacific Region. UNEP-WCMC/INBAR, Cambridge, UK.

Chao CS and Renvoize SA (1989) A revision of the species described under Arundinaria (Gramineae) in Southeast Asia and Africa. Kew Bulletin 44(2): 349-367.

Cred EM-DAT (Centre for Research on the Epidemiology of Disasters Emergency Events Database) (2017) The OFDA/CRED International Disaster Database. Cred EM-DAT, Brussels, Belgium. See http://www.emdat.be (accessed 13/01/2017).

HFP (Heritage Foundation of Pakistan) (2011a) Green Karavanghar. GKG and Beyond for Disaster Risk Reduction. HFP, Karachi, Pakistan.

HFP (2011b) Build Back Safer with Vernacular Methodologies. DRR-Driven Post-Flood Rehabilitation in Sindh. HFP, Karachi, Pakistan.

IFRC, UNHABITAT and UNHCR (International Federation of Red Cross and Red Crescent Societies, United Nations Human Settlements Programme, United Nations Refugee Agency) (2014) Pakistan 2010-2014 floods. Overview. In Shelter Projects 2013-2014 (Fowler J and Kennedy J (eds)). IFRC, Geneva, Switzerland, pp. 62-75.

IOM (International Organisation for Migration) (2014) Building Back Stronger. IOM, Islamabad, Pakistan.

Karim Alm-Ns I (2016) Market Survey Report of Bamboos. ACTED, Islamabad, Pakistan.

Lobovikov M, Paudel S, Piazza M, Ren H and Wu J (2007) World Bamboo Resources. A Thematic Study Prepared in the Framework of the Global Forest Resources Assessment 2005, Non Forest Products. Food and Agriculture Organization of the United Nations, Rome, Italy.

Rao VR and Ouedraogo AS (1997) Mountain bamboos and rattans: their genetic resources and conservation. In Proceedings of a Workshop Held at the Institute of Forestry, Pokhara, Nepal (Karki M, Rao AN, Ramanatha VR and Williams JT (eds)). INBAR, New Delhi, India, pp. 59-75.

Sharma B, Gatóo A, Bock M and Ramage M (2015) Engineered bamboo for structural applications. Construction and Building Materials 81: 66-73, https://doi.org/10.1016/j.conbuildmat.2015.01.077. Siddiqui KM (1994) A Note on Cultivation of Bamboos in Pakistan. Pakistan Forest Institute, Peshawar, Pakistan. 
Suleman KM (2005) Pakistan: Country Report on Bamboo Resources, Global Forest Assessment 2005. Food and Agriculture Organization of the United Nations, Peshawar, Pakistan. Trading Economics (2017) Pakistan Economic Indicators. Trading Economics, New York, NY, USA. See https://tradingeconomics. com/pakistan/indicators (accessed 24/07/2017).

Ward C, Abassi H, Gandapur SU et al. (2010) Emergency Market Mapping and Analysis. Pakistan Flood Response, 7-28 September 2010. Emma, Sindh, Pakistan, Sindh Final Report.

Zehui J (ed.) (2007) Bamboo and Rattan in the World. China Forestry Publishing House, Beijing, China.
ZRSAI (Ziegert Roswag Seiler Architekten Ingenieure) (2012) Locally-Manufactured Cob and Bamboo School Building. Lafarge Holcim Foundation, Jar Maulwi, Pakistan.

Zyck SA (2014) When Aid Goes Wrong: A Lesson from Pakistan on Why We Can't Ignore Markets. ODI, London, UK. See http://www.odi.org/comment/8881-pakistan-floods-marketsanalysis-shelter-humanitarian-mistakes (accessed 20/09/2016).

Zyck SA, Mosel I, Dad Khan H and Shabbir S (2015) Markets in Crises: The 2010 Floods in Sindh, Pakistan, HPG Working Paper. Humanitarian Policy Group at the Overseas Development Institute, London, UK.

\section{How can you contribute?}

To discuss this briefing, please email up to 500 words to the editor at journals@ice.org.uk. Your contribution will be forwarded to the author(s) for a reply and, if considered appropriate by the editorial board, it will be published as discussion in a future issue of the journal.

Proceedings journals rely entirely on contributions from the civil engineering profession (and allied disciplines).

Information about how to submit your paper online is available at www.icevirtuallibrary.com/page/authors, where you will also find detailed author guidelines. 